\section{Intracranial pressure and brain redox balance in rabbits}

Bruno Bissonnette MD, Phillip E. Bickler MD, PhD, George A. Gregory MD, John W. Severinghaus MD
The effects of elevated intracranial pressure (ICP) on intracellular oxygenation and cerebrocortical blood volume $(C B V)$ were studied in rabbits. Intracellular oxygen $\left(\mathrm{O}_{2}\right)$ concentration was assessed as the level of pyridine nucleotide concentration ([NADH])) oxidation/reduction balance and relative cerebrocortical blood volume (CBV) were measured with a fibreoptic fluororeflectometer probe placed on the cerebrocortical surface. Experiments were conducted in six urethane anaesthetized, normocarbic animals at different fractions of inspired $\mathrm{O}_{2}$ $\left(\mathrm{Fr}_{2}\right.$ ). During gradual increases in ICP. [NADH] began to increase (representing decreased intracellular mitochondrial $\mathrm{PO}_{2}$ ) for all values of $\mathrm{FIO}_{2}$ as ICP exceeded a threshold of $18 \pm$ $2.2 \mathrm{cmH}_{2} \mathrm{O}(P<0.05)$. The decline in intracellular oxygenation with elevated ICP was inversely related to $\mathrm{FlO}_{2}(P<0.05)$. With ICP greater than $18 \pm 2.2 \mathrm{cmH}_{2} \mathrm{O}$, intracellular mitochondrial oxygenation showed an improvement between an $\mathrm{F}_{1} \mathrm{O}_{2}$ of 0.21 and $0.5(P<0.05)$ but increasing $\mathrm{FlO}_{2}$ from 0.5 to 1.0 resulted in no statistically significant improvement in tissue redox balance. The $C B V$, largely representing tissue capillary blood, increased when ICP reached greater $18 \pm 1.2 \mathrm{cmH}_{2} \mathrm{O}$ probably reflecting local autoregulation or venous distension $(P$ $<0.05)$. However, above $30 \pm 1.1 \mathrm{cmH}_{2} \mathrm{O}, \mathrm{CBV}$ decreased $(P<0.05)$. The results demonstrate the interdependence of inspired oxygen concentration, elevated ICP, and brain intracellular oxygenation, and suggest that brain oxygen utilization deteriorates above an ICP of about $18 \mathrm{cmH}_{2} \mathrm{O}$.

\section{Key words}

BRAIN: cerebral blood volume, cortical metabolism, intracranial pressure;

MEASUREMENT TECHNIQUE: fuororeflectometry, pyridine nucleotide fluorescence;

METABOLISM: oxygen consumption, redox state.

From the Department of Anaesthesia and Cardiovascular Research Institute, University of California, San Francisco, CA 94143-0542, U.S.A. Presented, in part, at the Seventh International Symposium of Brain Injury and Intracranial Pressure, Ann Arbor, June 11-13, 1988.

Address correspondence to: Dr. Bruno Bissonnette, Department of Anaesthesia, The Hospital for Sick Children, 555 University Avenue, Toronto, Ontario, Canada, M5G 1X8. Accepted for publication 6th March, 1991.
Les effets d'une pression intracrânienne élevée (ICP) sur l'oxygénation intracellulaire et le volume sanguin cérébrocortical (CBV) on été étudiés chez les lapins. La concentration en oxygène intracellulaire $\left(\mathrm{O}_{2}\right)$ a été évaluée alors que le niveau de la balance oxidation/réduction de la concentration de nucléotide pyridine ([NADH]) et le volume sanguin cérébrocortical relatif (CBV) étaient mesurés à l'aide de la sonde d'un fluororéflectomètre à fibre optique placée à la surface cérébrocorticale. Les expériences ont été menées chez six animaux normocarbiques anesthésiés à l'uréthane et à différentes fractions d'oxygène inspiré $\left(\mathrm{F}_{1} \mathrm{O}_{2}\right)$. Lors des augmentations graduelles de ['ICP, la [NADH] a augmenté pour touses les valeurs de $\mathrm{FIO}_{2}$ lorsque l'ICP dépassait un seuil de $18 \pm 2.2 \mathrm{~cm}$ $\mathrm{H}_{2} \mathrm{O}$ (représentant une diminution de la $\mathrm{PO}_{2}$ mitochondriale intracellulaire) $(P<0,05)$. La diminution de l'oxygénation intracellulaire en relation avec une ICP élevée était inversement proportionnelle à la $\mathrm{FIO}_{2}(P<0,05)$. Avec une ICP plus grande que $18 \pm 2,2 \mathrm{~cm} \mathrm{H}_{2} \mathrm{O}$, l'oxygénation intracellulaire mitochondriale montrait une amélioration entre une $\mathrm{FrO}_{2}$ de $0,2 \mathrm{l}$ et de $0,5(P<0,05)$ mais l'augmentation de la $\mathrm{FlO}_{2} 0,5$ à 1,0 ne provoquait pas une amélioration statistiquement significative de la balance tissulaire réduction-oxydation. $L a C B V$, représentant principalement le sang capillaire tissulaire, augmentait lorsque l'ICP atteignait des valeurs de plus de $18 \pm 1,2 \mathrm{~cm}$ $\mathrm{H}_{2} \mathrm{O}$, probablement secondaire à l'autorégulation locale ou d une distension veineuse $(P<0,05)$. Cependant, à des valeurs au-dessus de $30 \pm 1, \mathrm{I} \mathrm{cm} \mathrm{H}_{2} \mathrm{O}$, la $\mathrm{CBV}$ diminuait $(P<0,05)$. Les résultats démontrent l'étroite dépendance entre la concentration d'oxygène inspirée, l'augmentation de l'ICP et l'oxygénation cérébrale intracellulaire, et suggère que l'utilisation cérébrale en oxygène se détériore à des valeurs de l'ICP d'environ $18 \mathrm{~cm} \mathrm{H}_{2} \mathrm{O}$

The unique and indispensible role of oxygen $\left(\mathrm{O}_{2}\right)$ in energy metabolism makes the problem of $\mathrm{O}_{2}$ supply to living tissues of material interest to all fields of medical biology. Under normal conditions, the brain is dependent upon a continuous supply of blood in order to obtain a continuous flow of $\mathrm{O}_{2}$ as well as glucose to the cells since they have a high rate of $\mathrm{O}_{2}$ utilization and low $\mathrm{O}_{2}$ and energy reserve. ${ }^{1}$ It is accepted that this flow occurs solely via the process of diffusion and that the driving force for this diffusion is the partial pressure difference between the 
capillary and the cell. ${ }^{2}$ Any alterations in the matching of cerebral blood flow (CBF) to $\mathrm{O}_{2}$ requirements may result in blockade of electron transport through the mitochodrial respiratory chain and a net decrease in ATP production. ${ }^{1.3}$ A basic variable of cellular metabolism is the oxidation/ reduction state. The redox state of cytoplasmic oxidized/ reduced pyridine nucleotide concentration ([NADH]/ $\left[\mathrm{NAD}^{+}\right]$) is the fundamental description of the status of energy transduction in the cell since both glycolysis and the Krebs cycle involve redox coupling with $\mathrm{NADH} /$ $\mathrm{NAD}^{+}$. Chance et al ${ }^{4}$ have shown that NADH is the most sensitive component to $\mathrm{O}_{2}$ utilization in the respiratory chain and therefore is most competent to serve as an indicator of intracellular $\mathrm{O}_{2}$ concentration. Various components of the respiratory chain exhibit different optical properties in the reduced and oxidized forms. ${ }^{5}$ Using the autofluorescence of the mitochondrial NADH, the excitation and emission spectra of NADH can be recorded using a fluorometer-reflectrometer-spectrophotometer on the surface of the living tissues. ${ }^{5-6}$

Elevated intracranial pressure (ICP) is an important pathophysiologic feature of head injury, post-ischaemic reperfusion, and a variety of disease states including cerebral oedema, infection, and haemorrhage. ${ }^{7}$ A reduction in blood flow to the brain and to the brain stem and consequent imbalance between oxygen supply and oxygen demand are viewed as the key mechanisms of injury due to elevated ICP. ${ }^{7-10}$ Despite the importance of these mechanisms, there is little information concerning the relationship of ICP to brain tissue oxygenation.

This study was designed to examine the effect of progressive changes in ICP on cerebrocortical oxygenation and CBV by measuring intracellular redox balance as an index of brain tissue oxygenation, using the technique of time-sharing multichannel fibreoptic fluoro-reflectrospectrophotometry.

$\begin{array}{ll}\text { Abbreviations } \\ \text { CBF: } & \text { cerebral blood flow } \\ \mathrm{CBV}: & \text { cerebrocortical blood volume } \\ \mathrm{CPP}: & \text { cerebral perfusion pressure } \\ \mathrm{CSF}: & \text { cerebral spinal fluid } \\ \mathrm{CF}: & \text { corrected fluorescence } \\ \mathrm{CVP}: & \text { central venous pressure } \\ \mathrm{FIO} & \text { fraction of inspired oxygen } \\ \mathrm{ICP}: & \text { intracranial pressure } \\ \mathrm{MAP}: \quad \text { mean arterial pressure } \\ {[\mathrm{NADH}]: \text { pyridine nucleotide, reduced concentration }} \\ {\left[\mathrm{NAD}^{+}\right]: \text {pyridine nucleotide, oxidized concentration }} \\ \mathrm{PaCO}_{2}: \quad \text { arterial carbon dioxide partial pressure } \\ \mathrm{PaO}_{2}: \quad \text { arterial oxygen partial pressure }\end{array}$

\section{Methods}

\section{Animal preparation}

With the approval of the Institutional Committee on Animal Research, mean arterial pressure (MAP), central venous pressure (CVP), and ICP were continuously recorded in six adult male New Zealand White rabbits. weighing $2.8-3.5 \mathrm{~kg}$. Anaesthesia was induced with urethane $20 \mathrm{mg} \cdot \mathrm{kg}^{-1}$ and muscle paralysis was induced with pancuronium $0.15 \mathrm{mg} \cdot \mathrm{kg}^{-1}$. The trachea was intubated and mechanical ventilation with $100 \% \mathrm{O}_{2}$ was established. The $\mathrm{PaCO}_{2}$ was maintained between 32-38 mmHg. Inspired and end-tidal $\mathrm{CO}_{2}, \mathrm{O}_{2}, \mathrm{~N}_{2}$ gas concentrations were analyzed with a Perkin-Elmer 1100 Mass Spectrometer (Perkin-Elmer, Norwalk, CT 06856). A thermistor rectal temperature probe was inserted and connected to a servocontrol heat lamp and a heating pad to maintain body core temperature at $39^{\circ} \mathrm{C}$.

The rabbit was placed in the prone position and the head was clamped in a stereotaxic apparatus. The scalp was retracted and a burr hole was drilled in the parietal bone for the insertion of an epidural pressure bolt. The bolt was cemented in place with eight per cent cyanoacrylate cement. A vertical $50 \mathrm{~cm}$ fluid-filled glass tube connected the bolt to a calibrated differential pressure transducer. A 22-gauge spinal needle was then inserted into the cisterna magna and connected to a mock cerebrospinal fluid (CSF) filled manometer. The mock CSF contained the following constituents in $\mathrm{mEq} \cdot \mathrm{L}^{-1}: \mathrm{Na}^{+} 151 ; \mathrm{K}^{+} 3 ; \mathrm{Ca}^{+} 2.5 ; \mathrm{Mg}^{+}$ $1.2 ; \mathrm{Cl}^{-} 134 ; \mathrm{HCO}_{3}^{-} 25$; urea 6 ; and dextrose 3.7.'1 Injections or withdrawals of mock CSF through this needle were made to control ICP. A second burr hole with a diameter of approximately $0.6 \mathrm{~cm}$ was made in the contralateral parietal bone to permit regional NADH and blood flow measurements. The dura-mater remained intact for this burr hole.

Measurements of tissue blood volume and oxygenation Cerebrocortical NADH fluorescence and ultraviolet reflectance were measured with a CF-1 fibreoptic timesharing fluorometer/reflectometer (Johnson Research Foundation, University of Pennsylvania) originally designed by Chance et al. ${ }^{12}$ and Jobsis et al. ${ }^{13}$ Mitochondrial NADH concentration was detected as an indirect measure of intracellular oxygenation. ${ }^{12}$ Excitation light with a wavelength of $366 \mathrm{~nm}$ was conveyed to the cerebrocortical surface by way of the central fibres of a trifurcated fibreoptic cable. The tip of the cable was positioned with a pressure-tight fit precisely at the level of surrounding cranium. The circumferential fibres of the cable returned the emitted NADH fluorescent light (450 $\mathrm{nm})$ and the reflected light $(366 \mathrm{~nm})$ from the tissue to the filtered photomultiplier tubes. When illuminated by the 
excitation light the reduced nucleotide NADH fluoresces at a wavelength of $450 \mathrm{~nm}$, whereas the oxidized NAD ${ }^{+}$ does not. ${ }^{12}$ Because the tissue haemoglobin concentration in the region illuminated by the fibreoptic probe absorbs some of the incident light, the amount of light reflected back to the fibreoptic light guide decreased when there was a larger volume of blood in the adjacent region $0-3 \mathrm{~mm}$ beyond the probe. Changes in the intensity of the reflected light can be used to estimate changes in CBV, which are proportional to changes in cerebrocortical blood flow. ${ }^{14}$

Artifactual changes in NADH fluorescence caused by changes in incident light intensity and from changes in blood volume in the detection region were corrected by the methods of Jobsis et al. ${ }^{13}$ and Harbig et al. ${ }^{15}$ The method is based on the observation that artifacts are proportional to the magnitude of reflected light. A proportionality constant is obtained as follows: a transient dilution of cerebrocortical blood is caused by the rapid injection of $0.3-0.7 \mathrm{ml}$ of normal saline into the ipsilateral carotid artery. The haemodilution transiently increases light intensity in both the fluorescence and reflectance channels. A corrected fluorescence (CF) is defined by assuming that the true concentration of cerebrocortical NADH did not change, although signal intensity was altered in both reflectance and fluorescence channels. The correction factor, $\mathrm{k}$, is the ratio of the haemodilutioninduced reflectance and fluorescence signals. True changes in tissue NADH are then calculated from the equation: $\Delta \mathrm{CF}=\Delta \mathrm{F}-\mathrm{k}(\Delta \mathrm{R})$, where $\Delta \mathrm{F}$ and $\Delta \mathrm{R}$ are the recorded changes in the signals measured at 450 and $366 \mathrm{~nm}$, respectively. ${ }^{16}$ Output signals of the two photomultiplier tubes were calibrated by equating the reflectance and fluorescence signals during ventilation with $100 \% \mathrm{O}_{2}$ and a $\mathrm{PaCO}_{2}$ maintained at $35-37 \mathrm{mmHg}$.

While we cannot measure the absolute level of NADH in the mitochondria, we can specify the change of NADH concentration at different $\mathrm{O}_{2}$ concentrations (e.g., hyperoxia, hypoxia, and anoxia) ${ }^{17}$ and compare the relative $\mathrm{NADH}$ variations at different $\mathrm{FIO}_{2}$ levels. The oxidationreduction state of pyridine nucleotide was calculated by expressing the compensated fluorescence intensity relative to the fluorescence value when the nucleotide pool was fully oxidized and fully reduced. The fully oxidized value was obtained by ventilating each animal with an atmosphere of $5 \% \mathrm{CO}_{2}$ in $\mathrm{O}_{2}$. This should result in luxury cerebral perfusion and maximal mitochondrial oxidation. The fully reduced signal was obtained after subjecting the brain to three to four minutes of anoxia at the end of each experiment. The redox state of the cytosolic NADH/ NAD ${ }^{+}$couple is a continuous function of $\mathrm{FIO}_{2}$ between 1.0 and $0.07 .{ }^{17}$ The fluorescence signal was expressed as a percentage of this range (relative [NADH]).

\section{Experimental protocol}

The experimental preparation was performed during intermittent positive pressure ventilation with $100 \% \mathrm{O}_{2}$. Normocarbia was maintained. The effect of changes in ICP on CBV and redox state was studied under conditions of different, constant fractions of inspired $\mathrm{O}_{2}(1.0,0.75$, $0.5,0.21$ ). At each $\mathrm{FrO}_{2}, \mathrm{ICP}$ was increased in a stepwise fashion, and steady-state values (less than five per cent change over five minutes) for redox balance, relative blood volume, and ICP were recorded. Blood pressure was maintained at a constant level by adjusting the level of anaesthesia and by intravenous fluid adminisration.

\section{Statistics}

The mean \pm standard deviation (SD) for $\mathrm{MAP}, \mathrm{PaCO}_{2}$, $\mathrm{PaO}_{2}, \mathrm{pH}$, and CVP were determined. Repeated-measures analysis of variance and the Tukey HPC test for multiple comparisons were used to determine statistical significance for within-group at each $\mathrm{FIO}_{2}$ for changes in $\mathrm{CBV}$ and [NADH]. One-way analysis of variance and the Tukey HPC test for multiple comparisons were used to determine statistical significance for intermediate $\mathrm{FIO}_{2}$ groups at each comparable level of ICP for CBV and [NADH]. A $P<0.05$ was considered statistically significant.

\section{Results}

A total of 42 steady-state measurement periods were made in six rabbits. Mean ( $\pm \mathrm{SD}$ ) values for MAP, $69 \pm 3.0$; $\mathrm{PaCO}_{2}, 37 \pm 0.02 ; \mathrm{pH}, 7.37 \pm 0.02 ;$ and $\mathrm{CVP}, 4.7 \pm 0.6$ were not significantly different among the different rabbits, or among different treatment periods in the same rabbit. The $\mathrm{PaO}_{2}$ obtained at $\mathrm{FIO}_{2}$ of $0.21,0.50,0.75$, and 1.00 were respectively $134.0 \pm 10.3,247.9 \pm 9.0$, $390.2 \pm 19.7$, and $505.3 \pm 14.9$. Vasoactive drugs were not used to control MAP during changes in ICP between 0 and $35 \mathrm{cmH}_{2} \mathrm{O}$.

Figure 1 shows the relationship between ICP and CBV, probably reflecting tissue capillary blood, at different levels of $\mathrm{FiO}_{2}$. While ICP was increased from normal to $18 \pm 1.2 \mathrm{cmH}_{2} \mathrm{O}, \mathrm{CBV}$ was inversely related for all values of $\mathrm{FIO}_{2}$. The $\mathrm{CBV}$ reached statistical significance only for $\mathrm{FIO}_{2}$ of 0.21 when compared with the other values of $\mathrm{FIO}_{2}$ at each ICP level below $18 \pm 1.2 \mathrm{cmH}_{2} \mathrm{O}(P<0.05)$. The CBV increased as ICP increased above $18 \pm 1.2$ $\mathrm{cmH}_{2} \mathrm{O}$ for all values of $\mathrm{FIO}_{2}(P<0.05)$, then declined dramatically when ICP passed $30 \pm 1.1 \mathrm{cmH}_{2} \mathrm{O}(P<$ 0.05 ). The rate of change of $\mathrm{CBV}$ above $18 \pm 1.2 \mathrm{cmH}_{2} \mathrm{O}$ in ICP was different from the baseline for each value of $\mathrm{FiO}_{2}(P<0.05)$ but there were no statistical differences among the values of $\mathrm{FIO}_{2}$ at each ICP above $18 \pm 1.2$ 


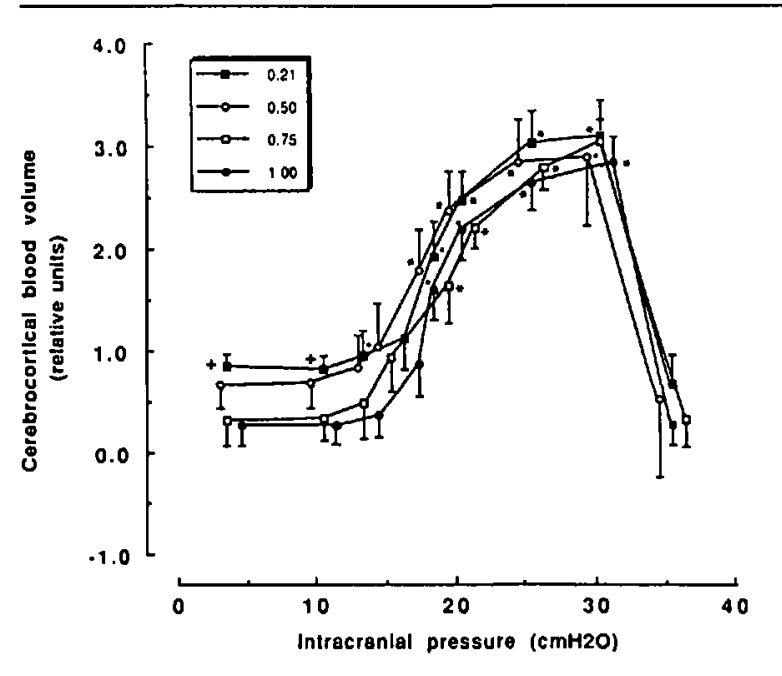

FIGURE 1 Effects of intracranial pressure on reflectometrically measured cortical blood volume. *Statistically significant differences within groups at each intracranial pressure level and the baseline of that group $(P<0.05)$. + Statistically significant differences among groups at each ICP level $(P<0.05)$. Bars represent \pm SD.

$\mathrm{cmH}_{2} \mathrm{O}$. The $\mathrm{CBV}$ observed at $35 \pm 0.9 \mathrm{cmH}_{2} \mathrm{O}$ was not statistically different from the baseline values of each value of $\mathrm{FIO}_{2}$.

Figure 2 shows the relationship of ICP to brain tissue oxygenation, expressed as relative cerebrocortical [NADH) levels. While ICP was increased from normal to $18 \pm 2.2 \mathrm{cmH}_{2} \mathrm{O}$ [NADH) was inversely related for all values of $\mathrm{FIO}_{2}$. The [NADH] was statistically different only for $\mathrm{FIO}_{2}$ of 0.21 when compared with the other values of $\mathrm{FlO}_{2}$ at each ICP level below $18 \pm 2.2 \mathrm{cmH}_{2} \mathrm{O}$ $(P<0.05)$. The [NADH] (representing decreased intramitochondrial $\mathrm{O}_{2}$ tension) increased as the ICP was increased above $18 \pm 2.2 \mathrm{cmH}_{2} \mathrm{O}$ for all levels of $\mathrm{FlO}_{2}(P$ $<0.05)$. This represented a cerebral perfusion pressure (CPP) of approximately $50 \mathrm{mmHg}$. The diminution in intramitochondrial $\mathrm{O}_{2}$ tension observed above $18 \pm 2.2$ $\mathrm{cmH}_{2} \mathrm{O}$ in ICP was statistically different from the baseline for each value of $\mathrm{FIO}_{2}(P<0.05)$. While increasing $\mathrm{F}_{1} \mathrm{O}_{2}$ from 0.21 to 0.5 caused a significant improvement in brain redox balance $(P<0.05)$, changing $\mathrm{FlO}_{2}$ from 0.5 to 1.0 had no statistically significant effect.

\section{Discussion}

This study demonstrated that inspired $\mathrm{O}_{2}$ concentration and ICP are both important variables affecting brain redox balance. A key finding was that cerebrocortical redox balance began to deteriorate as ICP was increased beyond $18 \pm 2.2 \mathrm{cmH}_{2} \mathrm{O}$, and this was independent of the level of inspired $\mathrm{O}_{2}$. At a given ICP, brain redox balance could be improved by increasing $\mathrm{F}_{1} \mathrm{O}_{2}$ from 0.21 to 0.50 but with

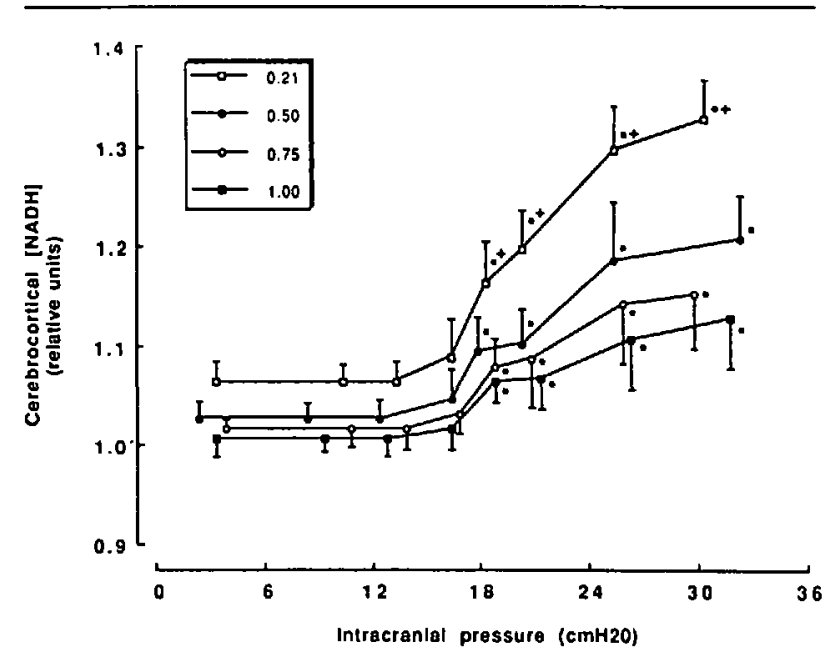

FIGURE 2 Effects of intracranial pressure on brain redox balance at different levels of inspired $\mathrm{O}_{2}$. ${ }^{*}$ Statistically significant differences within groups at each intracranial pressure level and the baseline of that group $(P<0.05)$. + Statistically significant differences among groups at each ICP level $(P<0.05)$. Bars represent \pm SD.

diminishing effect above an $\mathrm{FIO}_{2}$ of 0.5 . A gradual increase in NADH fluorescence was detected as ICP was increased above $18 \mathrm{cmH}_{2} \mathrm{O}$. This suggests that a change in intracellular $\mathrm{O}_{2}$ availability began to occur as CPP decreased below about $50 \mathrm{mmHg}$. The MAP was constant in these experiments until ICP exceeded $35-40 \mathrm{cmH}_{2} \mathrm{O}$. The NADH fluorescence was observed to be a function of inspired oxygen level, even within the normoxic range. This is consistent with previous observations in rabbits, ${ }^{16}$ but it is at odds with in vitro data from isolated mitochondria that show that maintenance of normal redox balance are independent of arterial oxygen concentration until a critical concentration is reached. ${ }^{18}$ It is noteworthy that a relationship seems to exists between the predicted defect in brain-tissue oxygen supply and the cerebral venous oxygen-tension values. ${ }^{18} \mathrm{Few}$ studies have examined the effect of changing $\mathrm{FIO}_{2}\left(\mathrm{PaO}_{2}\right)$ on redox balance in vivo. A continous relationship between NADH fluorescence and $\mathrm{O}_{2}$ availability in vivo probably reflects a steep $\mathrm{O}_{2}$ diffusion gradient between arterial blood and mitochodrion.

Increasing NADH fluorescence occurred with increasing ICP even though local CBV appeared to increase. Several factors may have contributed to this occurrence. Firstly; it is important to recognize the limitations of reflectometric measurements of blood flow. Usually, brain blood volume correlates well with global cerebral blood flow ${ }^{13}$ and reflectometric measurements of CBV correlate well with changes in cerebral blood flow caused, for example, by increasing $\mathrm{PaCO}_{2} .{ }^{15}$ Under conditions of 
increased ICP this may not be so. It is generally accepted that intravascular pressure must be slightly greater than brain-tissue or ICP pressure or the more compliant vessels would collapse. ${ }^{19}$ Mild venous outflow obstruction may occur at $18 \pm 1.2 \mathrm{cmH}_{2} \mathrm{O}$, and increases up to about $30 \pm$ $1.1 \mathrm{cmH}_{2} \mathrm{O}$. Above $30 \pm 1.1 \mathrm{cmH}_{2} \mathrm{O}$, tissue blood volume decreases precipitously as venous outflow is collapsed or blood is squeezed from the tissue by the pressure applied against the reflectometric probe. Thus, reflectometric measurements of tissue blood volume may not reflect blood flow during high ICP elevation. Secondly, since increases in brain tissue blood volume were seen as ICP increased above the level causing increased $\mathrm{NADH}$, the increase in blood volume may reflect autoregulatory vasodilation in brain surface vessels. Clearly, independent methods of blood flow measurement are needed to distinguish between these possibilities.

Previous work in our laboratory has demonstrated the physiological relevance of our techniques of in vivo fibreoptic fluorometry. ${ }^{16}$ Measurements of brain and redox state are sensitive to perturbations of blood pressure, $\mathrm{PaCO}_{2}, \mathrm{PaO}_{2}$, haemorrhage, haemodilution, and treatments with cyanide or acetazolamide. Because the fibreoptic probe used in these experiments was positioned flush with the internal surface of the cranium with an intact dura-mater, brain redox measurement did not interfere with ICP.

Urethane is a commonly used veterinary anaesthetic and its use is routine for studies of the central nervous system due to its lack of effect on systemic haemodynamics and its minimal impact on cerebral physiology. ${ }^{20,21}$ It is unlikely that urethane obscured the true effects of changes in oxygen delivery and ICP on brain redox balance.

The results of this study suggest that even mild increases in ICP cause measurable decreases in brain oxygenation. These changes can be ameliorated by increasing the $\mathrm{FIO}_{2}$, but at higher levels of ICP, increased $\mathrm{FIO}_{2}$ has diminished effect on brain redox balance. This is

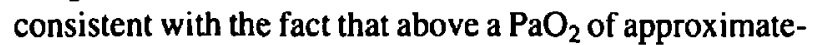
ly $100 \mathrm{mmHg}$, little additional gain in $\mathrm{O}_{2}$ transport is achieved by increasing $\mathrm{PaO}_{2}$.

This conclusion may have relevance in human intensive care settings where ventilator management of patients with intracranial injury takes place. However, further investigation is required to confirm this relevance.

\section{Acknowledgement}

The authors would like to thank Dr. John E.S. Relton for his advice in the preparation of this manuscript.

\section{References}

1 Mayersky $A$. NADH redox state monitored in vivo by fibreoptic surface fluorometry. Brain Res Rev 1984; 7 : 49-68.

2 Thews $G$. Selective vulnerability of the brain in hypoxaemia. 1st ed. Oxford: Blackwell Scientific Publications, 1963.

3 Jöbsis FF, Rosenthal M. Bchaviour of the mitochondrial respiratory chain in vivo. Ciba Foundation Symposium 1978; 56: 149-69.

4 Chance B, Oshino N, Sugano T, Mayevsky A. Basic principles of tissue oxygen determination from mitochondrial signals. Exp Med Biol 1973; 37: 277-92.

5 Chance B, Legallais $V$, Sorge J, Craham N. A verstile time-sharing multichannel spectrophotometer, reflectrometer, and fluorometer. Anal Biochem 1975; 66: 498-514.

6 Bücher T, Brauser B, Conze A et al. State of oxidationreduction and state of binding in the cytosolic NADHsystem as disclosed by equilibration with extracellular lactate/pyruvate in hemoglobin-free perfused rat liver. Eur J Biochem 1972; 27: 301-17.

7 Shapiro $H$. Neurosurgical anesthesia and intracranial hypertension. In: Miller RD (Ed.). Anesthesia, 2nd ed., New York: Churchill-Livingstone Inc., 1986; 1563-620.

8 Muizelaar JP, Marmarou A, DeSalles AA et al. Cerebral blood flow and metabolism in severely head-injured children. J Neurosurg 1989: 71: 63-71.

9 Obrist WD, Langfitt TW, Jaggi JL, Cruz J, Gennarelli $T A$. Cerebral blood flow and metabolism in comatose patients with acute head injury. J Neurosurg 1984; 61: 241-53.

10 Frewen TC, Sumabat WO, Del Maestro F. Cercbral blood flow, mctabolic rate, and cross-brain oxygen consumption in brain injury. J Pediatr 1985; 107: 510-3.

11 Koehler RC, Traystman RJ. Bicarbonate ion modulation of cerebral blood flow during hypoxia and hypercapnia. Am J Physiol 1982; 243: H33-H40.

12 Chance $B$, Cohen $P$, Jobsis $F$ et al. Intracellular oxidationreduction states in vivo. Science 1962; 137: 499-508.

13 Jöbsis $F F, O^{\prime}$ Connor $M J$, Vitale A et al. Intracellular redox changes in functioning cerebral cortex. $J$ Neurophysiol 1971; 34: 735-49.

14 Risberg J, Ancri D, Ingvar $H$. Correlation between cerebral blood volume and cerebral blood flow in the cat. Exp Brain Res 1969; 8: 321-6.

15 Harbig $K$, Chance B. Kovach $A G B$ et al. In vivo measurement of pyridine nuclcotide fluorescence from cat brain cortex. J Appl Physiol 1976; 41: 480-8. 
16 Bickler PE, Litt L, Severinghaus JW. Effects of acetazolamide on cerebrocortical NADH and blood volume. J Appl Physiol 1988; 65: 428-33.

17 Chance $B$, Williams $G R$. Respiratory enzymes in oxidative phosphorylation. I. Kinetics of oxygen utilization. J Biol Chem 1955; 217: 383-93.

18 Lübbers DW, Kessler $M$. Oxygen transport in blood and tissues. Stuggart; Georg Thieme, Verlag, 1968; 124-39.

19 Marmarou A, Maset AL, Ward ID et al. Contribution of CSF and vascular factors to elevation of ICP in severely head-injured patients. J Neurosurg 1987; 66: 883-90.

20 Maggi CA, Meli $A$. Suitability of urethane anesthesia for physiopharmacological investigations in various systems. Part 1: General considerations. Experientia 1986: 42 : $109-14$.

21 Maggi CA, Meli A. Suitability of urethane anesthesia for physiopharmacological investigations in various systems. Part 1: Cardiovascular system. Experientia 1986; 42: 292-7. 